Article

\title{
Extracts from Six Native Plants of the Yucatán Peninsula Hinder Mycelial Growth of Fusarium equiseti and F. oxysporum, Pathogens of Capsicum chinense
}

\author{
Patricia Cruz-Cerino ${ }^{1, * \mathbb{D}}$, Jairo Cristóbal-Alejo ${ }^{2}$, Violeta Ruiz-Carrera ${ }^{3}$, Germán Carnevali ${ }^{4,5}$, \\ Marina Vera-Ku ${ }^{4}$, Jesús Martín ${ }^{6}$, Fernando Reyes ${ }^{6}$ (D) and Marcela Gamboa-Angulo ${ }^{1, *(D)}$ \\ 1 Unidad de Biotecnología, Centro de Investigación Científica de Yucatán, 97205 Mérida, Mexico \\ 2 Laboratorio de Fitopatología, Tecnológico Nacional de México, Instituto Tecnológico de Conkal, \\ 97345 Conkal, Mexico; jairo.cristobal@itconkal.edu.mx \\ 3 Laboratorio de Biotecnología, Universidad Juárez Autónoma de Tabasco, 86039 Villahermosa, Mexico; \\ violeta@ujat.mx \\ 4 Unidad de Recursos Naturales, Centro de Investigación Científica de Yucatán, Chuburná de Hidalgo, \\ 97205 Mérida, Mexico; carneval@cicy.mx (G.C.); marina.vera@cicy.mx (M.V.-K.) \\ 5 Orchid Herbarium of Oakes Ames, Harvard University Herbaria, Cambridge, MA 02138, USA \\ 6 Fundación MEDINA, 18016 Granada, Spain; jesus.martin@medinaandalucia.es (J.M.); \\ fernando.reyes@medinaandalucia.es (F.R.) \\ * Correspondence: patricia.cruz@cicy.mx (P.C.-C.); mmarcela@cicy.mx (M.G.-A.); \\ Tel.: +52-999-942-8330 (M.G.-A.)
}

Received: 18 August 2020; Accepted: 6 October 2020; Published: 10 October 2020

\begin{abstract}
Fusarium equiseti strain FCHE and Fusarium oxysporum strain FCHJ were isolated from the roots of wilting habanero pepper (Capsicum chinense Jacq.) seedlings with root rot. Toward developing a biorational control of these serious phytopathogenic strains, ethanolic (EE) and aqueous (AE) extracts of different vegetative parts of 40 tropical native plants of the Yucatán Peninsula were screened for antifungal activity. Extracts of six out of 40 assayed plants were effective, and the most inhibitory extracts were studied further. EEs from Mosannona depressa (bark from stems and roots), Parathesis cubana (roots), and Piper neesianum (leaves) inhibited mycelial growth of both strains. Each active EE was then partitioned between hexane and acetonitrile. The acetonitrile fraction from M. depressa stem bark (MDT-b) had the lowest minimum inhibitory concentration of $1000 \mu \mathrm{g} / \mathrm{mL}$ against both pathogens and moderate inhibitory concentration $\left(\mathrm{IC}_{50}\right)$ of 462 against $F$. equiseti and $472 \mu \mathrm{g} / \mathrm{mL}$ against $F$. oxysporum. After $96 \mathrm{~h}$ treatment with EE from M. depressa stem bark, both strains had distorted hyphae and conidia and collapsed conidia in scanning electron micrographs. Liquid chromatography-ultraviolet-high resolution mass spectrometry analysis revealed that the major component of the fraction was $\alpha$-asarone. Its antifungal effect was verified using a commercial standard, which had an $\mathrm{IC}_{50}$ of $236 \mu \mathrm{g} / \mathrm{mL}$ against $F$. equiseti and $>500 \mu \mathrm{g} / \mathrm{mL}$ against $F$. oxysporum. Furthermore, the P. cubana hexane fraction and P. neesianum acetonitrile fraction had antifungal activity against both Fusarium pathogens. These compounds provide new options for biorational products to control phytopathogenic fungi.
\end{abstract}

Keywords: antifungal; $\alpha$-asarone; habanero pepper; phytopathogens; Mosannona depressa; plant extracts 


\section{Introduction}

Approximately 200 species of Fusarium are recognized as pathogens of a broad range of plants, and F. graminearum and F. oxysporum were ranked in fourth and fifth place among the top 10 scientifically or economically most important fungal pathogens [1]. In pepper (Capsicum spp.) crops, serious post-harvest losses are caused by F. oxysporum [2]. Peppers from about 35 Capsicum species are consumed, most widely from C. annuum, C. baccatum, C. frutescens, C. pubescens and C. chinense, which have been the most successfully domesticated and cultivated [3]. México reported an annual production of 3.2 million tons of pepper crops and average annual growth in production of $4.82 \%$ during 2003-2016 [4]. In particular, habanero peppers (C. chinense) are appreciated worldwide for their high content of capsaicin, the main alkaloid responsible for their hotness [5]. Capsaicin is also beneficial as a cardioprotective, anti-inflammatory, analgesic and a gastrointestinal aid and for its thermogenic properties [6]. In the chemical industry, it is useful in the production of paints and varnishes, tear gas and other compounds. In the Yucatán Peninsula, habanero peppers are part of the culinary identity as a condiment [7]. The habanero pepper from the Yucatán Peninsula Denomination of Origin (NOM-189-SCFI-2017) is presently cultivated on 1134 ha [8], and its production has been increasing steadily in recent years. However, Fusarium spp. cause production losses of at least $50 \%$ or even $100 \%$ when conditions are favorable [9]. F. oxysporum and F. equiseti, which infect the roots of habanero pepper seedlings and cause root rot and wilting in the Yucatán Peninsula, México [10], also produce mycotoxins such as fumonisins and trichothecenes in crops and feed products and represent a risk to human health [11].

Currently, the management of Fusarium species depends on the intensive use of synthetic fungicides such as a benomyl, carbendazim, thiabendazole and alliete [12]. However, such intensive use can induce resistance in the pathogen and negatively impact the environment, beneficial microorganisms and humans by acting as a skin irritant and carcinogen $[13,14]$. To reduce dependence on synthetic pesticides, numerous strategies, such as the rotation of crops, use of resistant cultivars and biorational products and solarization of the soils, are thus integrated into a pest management program $[15,16]$. Natural products derived from plants are a highly viable option as biorational antifungal products that should leave less environmental residue and be nontoxic to beneficial organisms and humans $[17,18]$

To discover and incorporate new antifungal agents in the control of diseases caused by Fusarium species, several groups have tested plant extracts in vitro and in vivo [19-21]. The high plant diversity in Mexico, with 23,314 reported species, 50\% of which are endemic, has scarcely been explored for their biological and chemical properties. In the Yucatán Peninsula, the 2330 known species of vascular plants, belonging to 956 genera and 161 families, represent $6 \%$ of the Mexican flora [22,23]. Previous bioprospecting of Yucatecan native plant extracts for activity against phytopathogenic fungi has revealed good fungicidal properties of extracts from plants such as Acacia pennatula, Acalypha gaumeri and Croton chichenensis [24-26].

Because of the increasing demand for natural fungicides to control habanero pepper diseases, more bioprospecting programs have been needed. Therefore, here, we screened 184 extracts from 40 plant species native to the Yucatán Peninsula for activity against F. equiseti FCHE and F. oxysporum FCHJ strains from habanero pepper (Table 1), examined hyphae using scanning electron microscopy (SEM) for any morphological effects of the active extracts and analyzed the chemical profile of the active fractions obtained from active extracts using liquid chromatography-ultraviolet-high-resolution mass spectrometry (LC-UV-HRMS). 
Table 1. Plants collected from the Yucatán Peninsula to screen for activity against F. equiseti strain FHCE and F. oxysporum strain FCHJ.

\begin{tabular}{|c|c|c|c|c|c|}
\hline Species & Local Name $^{a}$ & Family & Site & Voucher & Plant Parts Usec \\
\hline Alseis yucatanensis Standl. & ja'as che' & Rubiaceae & Kiuic & JLT-3179 & $\mathrm{L}$ \\
\hline Alvaradoa amorphoides Liebm. & bel siinik che' & Simaroubaceae & Jahuactal & GC-8236 & $\mathrm{L}, \mathrm{S}, \mathrm{R}$ \\
\hline Annona primigenia Standl. \& Steyerm & & Annonaceae & Jahuactal & GC-8057 & $\mathrm{L}, \mathrm{SB}$ \\
\hline Bakeridesia notolophium (A. Gray) Hochr. & & Malvaceae & Punta Pulticub & RD-s/n & $\mathrm{L}, \mathrm{S}$ \\
\hline Bravaisia berlandieriana (Nees) T.F.Daniel & Juluub & Acanthaceae & Punta Laguna & GC- -8168 & $\mathrm{~L}, \mathrm{~S}, \mathrm{R}$ \\
\hline Byrsonima bucidifolia Standl. & & Malpighiaceae & Jahuactal & GC-8087 & $\mathrm{L}, \mathrm{S}, \mathrm{R}$ \\
\hline Calea jamaicensis (L.) L. & tu' xikin & Asteraceae & Jahuactal & GC-8084 & WP \\
\hline Cameraria latifolia $\mathrm{L}$. & cheechen blanco & Apocynaceae & Jahuactal & JLT-1165 & $\mathrm{L}, \mathrm{SB}, \mathrm{R}$ \\
\hline Chrysophyllum mexicanum Brandegee ex Standl. & chi'kéej & Sapotaceae & Jahuactal & GC-8082 & $\mathrm{L}, \mathrm{S}, \mathrm{R}$ \\
\hline Coccoloba sp. & & Polygonaceae & Xmaben & GC- 8258 & $\mathrm{~L}, \mathrm{~S}$ \\
\hline Croton arboreus Millsp. & pak che' & Euphorbiaceae & Jahuactal & JLT-1132 & $\mathrm{L}, \mathrm{S}, \mathrm{R}$ \\
\hline Croton itzaeus Lundell & & Euphorbiaceae & Jahuactal & JLT-1138 & L, SB, RB \\
\hline Croton sp. & & Euphorbiaceae & Xmaben & GC-8262 & WP \\
\hline Cupania sp. & & Sapindaceae & Chacchoben Limones & GC-8009 & $\mathrm{L}, \mathrm{S}$ \\
\hline Diospyros sp. & & Ebenaceae & Punta Laguna & GC-8147 & $\mathrm{L}$ \\
\hline Erythroxylum confusum Britton & & Erythroxylaceae & Jahuactal & JLT-1143 & $\mathrm{L}, \mathrm{S}, \mathrm{R}$ \\
\hline Erythroxylum rotundifolium Lunan & baak soots' & Erythroxylaceae & Jahuactal & GC-8179 & $\mathrm{L}, \mathrm{S}$ \\
\hline Erythroxylum sp. & & Erythroxylaceae & Punta Laguna & GC-8137 & L \\
\hline Eugenia sp. & & Myrtaceae & Punta Laguna & GC-8127 & $\mathrm{L}, \mathrm{S}, \mathrm{R}$ \\
\hline Euphorbia armourii Millsp. & kabal chakaj & Euphorbiaceae & Kaxil Kiuic & JLT-3182 & WP \\
\hline Guettarda combsii Urb. & & Rubiaceae & Jahuactal & GC-8047 & $\mathrm{L}, \mathrm{SB}, \mathrm{RB}$ \\
\hline Helicteres baruensis Jacq. & Sutup & Malvaceae & Kaxil Kiuic & GC-8127 & $\mathrm{L}, \mathrm{S}, \mathrm{R}$ \\
\hline Heteropterys laurifolia (L.) A. Juss. & chilillo aak' & Malpighiaceae & Jahuactal & GC-8035 & $\mathrm{L}, \mathrm{SB}, \mathrm{R}$ \\
\hline Hybanthus yucatanensis Millsp. & & Violaceae & Punta Laguna & GC-8158 & $\mathrm{L}, \mathrm{S}$ \\
\hline Ipomoea clavata (G. Don) Ooststr. ex J.F.Macbr. & ulu'um ja' & Convolvulaceae & Kaxil Kiuic & JLT-3181 & WP \\
\hline Karwinskia humboldtiana (Willd. ex Roem. \& Schult.) Zucc. & I u'um che' & Rhamnaceae & Kaxil Kiuic & JLT-3188 & $\mathrm{L}$ \\
\hline Licaria sp. & & Lauraceae & Jahuactal & GC-8037 & L, SB, RB \\
\hline Macroscepis diademata (Ker Gawl.) W.D. Stevens & aak'tóom paap & Apocynaceae & Kaxil Kiuic & JLT-3187 & L, SB \\
\hline Malpighia glabra L. & & Malpighiaceae & Punta Laguna & GC-8144 & $\mathrm{L}, \mathrm{S}, \mathrm{R}$ \\
\hline Morella cerifera (L.) Small. & & Myricaceae & Jahuactal & JLT-1137 & L, S, RB \\
\hline Mosannona depressa (Ball.) Chatrou & sak éelemuy & Annonaceae & Jahuactal & GC- 8085 & $\mathrm{~L}, \mathrm{SB}, \mathrm{RB}$ \\
\hline Parathesis cubana (A. DC.) Molinet \& M.Gómez & & Primulaceae & Jahuactal & JLT-1133 & $\mathrm{L}, \mathrm{SB}, \mathrm{RB}$ \\
\hline Paullinia sp. & & Sapindaceae & Punta Laguna & GC-8106 & $\mathrm{L}, \mathrm{R}$ \\
\hline Piper neesianum C.DC. & & Piperaceae & Jahuactal & GC- -8080 & $\mathrm{~L}, \mathrm{~S}, \mathrm{R}$ \\
\hline Psychotria sp. & & Rubiaceae & Jahuactal & GC-8086 & WP \\
\hline Randia aculeata $\mathrm{L}$. & kat ku'uk & Rubiaceae & Punta Laguna & GC-8156 & $\mathrm{L}, \mathrm{S}, \mathrm{R}$ \\
\hline Serjania caracasana (Jacq.) Willd & & Sapindaceae & Punta Laguna & GC-8114 & L, S, R \\
\hline Simarouba glauca DC. & & Simaroubaceae & Jahuactal & GC-8081 & $\mathrm{L}, \mathrm{SB}, \mathrm{RB}$ \\
\hline Stemmadenia donnell-smithii (Rose) Woodson & & Apocynaceae & Jahuactal & GC-8056 & L, SB \\
\hline Turnera aromatica Arbo & & Passifloraceae & Jahuactal & GC-8081 & WP \\
\hline
\end{tabular}

${ }^{a}$ [27]; SB: stem bark; RB: root bark; L: leaves; S: stem; R: root; WP: whole plant. 


\section{Results}

\subsection{Antifungal Activity of Plant Extracts Against Fusarium spp.}

Table 2 shows the results of active plant extracts on mycelial growth of $F$. equiseti FCHE and F. oxysporum FCHJ. Ethanolic extracts (EEs) from Mosannona depressa (bark of stem and root), Parathesis cubana (root) and Piper neesianum (leaves) at $2000 \mu \mathrm{g} / \mathrm{mL}$ and aqueous extracts (AE) from Cameraria latifolia (root), Calea jamaicensis (whole plant) and Heteropterys laurifolia (leaves) at 3\% w/v were active against one or both Fusarium strains after $96 \mathrm{~h}$. All these active extracts inhibited mycelial growth of F. equiseti, but only four EEs inhibited mycelial growth of F. oxysporum. No active AEs were detected against F. oxysporum.

Table 2. Inhibition of mycelial growth of Fusarium equiseti strain FCHE and F. oxysporum strain FCHJ by active plant extracts from native species of the Yucatán Peninsula in microdilution assay.

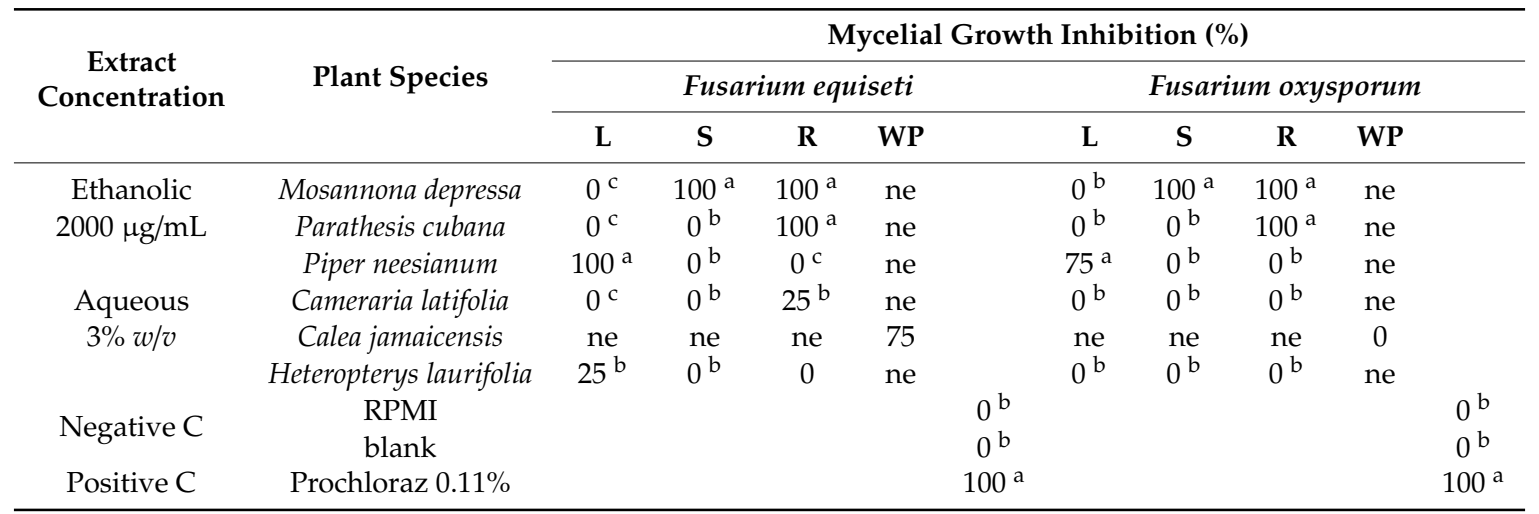

C: control; L: leaves; S: stem, R: root; WP: whole plant; RPMI: Roswell Park Memorial Institute medium; ne: not evaluated; blank: dimethyl sulfoxide with $0.5 \%$ Tween 20 . a, b, $c$ : means with different letters within columns differ significantly (Tukey's test, $p<0.05$ ). Extracts from M. depressa were from bark of stems and roots.

Complete mycelial growth inhibition (MGI of 100\%) for both phytopathogens was achieved with EEs from $M$. depressa bark of stems and P. cubana roots. The EE from leaves of P. neesianum was also effective (MGI of $100 \%$ against F. equiseti and 75\% against F. oxysporum). The AE from C. jamaicensis also achieved $75 \%$ MGI against F. equiseti. The EAs from C. latifolia root and H. laurifolia leaves achieved MGI of only $25 \%$ against F. equiseti (Table 2). On the other hand, none of the EAs had any activity against F. oxysporum. The positive control, prochloraz $(0.11 \%)$, completely inhibited the growth of the two phytopathogens, and typical mycelial growth of both plant pathogens was observed for the negative controls. The other plant extracts did not cause significant mycelial growth inhibition with respect to the negative control (Supplementary Table S1).

\subsection{Minimum Inhibitory Concentration of Ethanolic Extracts, Fractions and $\alpha$-Asarone}

The minimum inhibitory concentration (MIC) of the four EEs that completely inhibited mycelial growth of both Fusarium strains was determined. F. equiseti was more sensitive to the extracts from $M$. depressa stem bark, P. cubana roots and P. neesianum leaves (MIC: $1000 \mu \mathrm{g} / \mathrm{mL}$ ). All these active extracts were fungicidal, except for the extract from leaves of P. neesianum, which was fungistatic (Table 2). In contrast, F. oxysporum was less sensitive to the four EEs, which were fungistatic and had MICs of $2000 \mu \mathrm{g} / \mathrm{mL}$. Therefore, the four EEs were partition-fractionated, and serial dilutions of each fraction (hexane, acetonitrile and a methanol-soluble precipitate) were tested for activity.

The most active fractions against F. oxysporum were the hexane (MDT-a) and acetonitrile (MDT-b) fractions from $M$. depressa stem bark, which were both fungistatic, and the hexane fraction from P. cubana roots (PCR-a), which was fungicidal; all had a MIC of $1000 \mu \mathrm{g} / \mathrm{mL}$ (Table 3). As expected, a fungicidal effect on F. equiset $i$ was induced by half of the fractions, with a MIC of $1000 \mu \mathrm{g} / \mathrm{mL}$. These fractions were the same as those that inhibited F. oxysporum: the acetonitrile fraction from P. neesianum leaves (PNH-b), 
precipitates of P. cubana roots (PCR-c) and P. neesianum leaves (PNH-c). The fractions obtained from the root bark and the precipitate of the stem bark of $M$. depressa were considered as inactive against the two pathogens because their MIC was greater than $1000 \mu \mathrm{g} / \mathrm{mL}$ (Table 3).

The MIC of the commercial $\alpha$-asarone standard, evaluated in parallel with the fractions, was $500 \mu \mathrm{g} / \mathrm{mL}$ against $F$. equiseti with fungistatic effect, and $>500 \mu \mathrm{g} / \mathrm{mL}$ against F. oxysporum (Table 3).

Table 3. Minimum inhibitory concentration (MIC) of extracts and fractions from Mosannona depressa (bark of stems and roots), P. cubana (roots), P. neesianum (leaves) and $\alpha$-asarone against Fusarium equiseti strain FCHE and F. oxysporum strain FCHJ.

\begin{tabular}{|c|c|c|c|c|c|c|c|c|c|c|c|}
\hline \multirow{3}{*}{$\begin{array}{l}\text { Extract/ } \\
\text { Fraction }\end{array}$} & \multirow{3}{*}{ Solvent } & \multicolumn{5}{|c|}{ Fusarium equiseti } & \multicolumn{5}{|c|}{ Fusarium oxysporum } \\
\hline & & \multicolumn{10}{|c|}{ Concentration of Extracts $(\mu \mathrm{g} / \mathrm{mL})$} \\
\hline & & 2000 & 1000 & 500 & 250 & MIC & 2000 & 1000 & 500 & 250 & MIC \\
\hline MDT & $\mathrm{E}$ & $100^{\mathrm{a}}$ & $100^{a}$ & $75^{c}$ & $0^{\mathrm{c}}$ & $1000++$ & $100^{\mathrm{a}}$ & $75^{\mathrm{b}}$ & $0^{f}$ & $0^{b}$ & $2000+$ \\
\hline MDT-a & $\mathrm{H}$ & ne & $100^{a}$ & $0^{\mathrm{e}}$ & $0^{\mathrm{c}}$ & $1000++$ & ne & $100^{a}$ & $0^{f}$ & $0^{b}$ & $1000+$ \\
\hline MDT-b & $\mathrm{A}$ & ne & $100^{\mathrm{a}}$ & $83^{b}$ & $0^{\mathrm{c}}$ & $1000++$ & ne & $100^{\mathrm{a}}$ & $75^{b}$ & $0^{b}$ & $1000+$ \\
\hline MDT-c & $\mathrm{P}$ & ne & $75^{c}$ & $50^{d}$ & $0^{c}$ & $>1000$ & ne & $75^{b}$ & $50^{d}$ & $0^{\mathrm{b}}$ & $>1000$ \\
\hline MDR & $\mathrm{E}$ & $100^{a}$ & $83^{b}$ & $0^{\mathrm{e}}$ & $0^{\mathrm{c}}$ & $2000++$ & $100^{\mathrm{a}}$ & $75^{b}$ & $0^{\mathrm{f}}$ & $0^{\mathrm{b}}$ & $2000+$ \\
\hline MDR-a & $\mathrm{H}$ & ne & $0^{d}$ & $0^{\mathrm{e}}$ & $0^{\mathrm{c}}$ & $>1000$ & ne & $0^{\mathrm{d}}$ & $0^{\mathrm{f}}$ & $0^{\mathrm{b}}$ & $>1000$ \\
\hline MDR-b & $\mathrm{A}$ & ne & $75^{c}$ & $0^{\mathrm{e}}$ & $0^{\mathrm{c}}$ & $>1000$ & ne & $0^{d}$ & $0^{\mathrm{f}}$ & $0^{\mathrm{b}}$ & $>1000$ \\
\hline MDR-c & $\mathrm{P}$ & ne & $83^{b}$ & $50^{d}$ & $0^{\mathrm{c}}$ & $>1000$ & ne & $75^{b}$ & $50^{d}$ & $0^{\mathrm{b}}$ & $>1000$ \\
\hline PCR & $\mathrm{E}$ & $100^{a}$ & $100^{a}$ & $0^{\mathrm{e}}$ & $0^{\mathrm{c}}$ & $1000++$ & $100^{a}$ & $58^{c}$ & $25^{\mathrm{e}}$ & $0^{\mathrm{b}}$ & $2000+$ \\
\hline PCR-a & $\mathrm{H}$ & ne & $100^{a}$ & $0^{\mathrm{e}}$ & $0^{\mathrm{c}}$ & $1000++$ & ne & $100^{a}$ & $0^{\mathrm{f}}$ & $0^{\mathrm{b}}$ & $1000++$ \\
\hline PCR-b & A & ne & $100^{a}$ & $0^{\mathrm{e}}$ & $0^{\mathrm{c}}$ & $1000++$ & ne & $0^{\mathrm{d}}$ & $0^{\mathrm{f}}$ & $0^{b}$ & $>1000$ \\
\hline PCR-c & $\mathrm{P}$ & ne & $0^{d}$ & $0^{\mathrm{e}}$ & $0^{\mathrm{c}}$ & $>1000$ & ne & $0^{d}$ & $0^{f}$ & $0^{\mathrm{b}}$ & $>1000$ \\
\hline $\mathrm{PNH}$ & $\mathrm{E}$ & $100^{a}$ & $100^{a}$ & $0^{\mathrm{e}}$ & $0^{\mathrm{c}}$ & $1000+$ & $75^{b}$ & ne & ne & ne & $2000+$ \\
\hline PNH-a & $\mathrm{H}$ & ne & $0^{\mathrm{d}}$ & $0^{\mathrm{e}}$ & $0^{\mathrm{c}}$ & $>1000$ & ne & ne & ne & ne & \\
\hline PNH-b & $\mathrm{A}$ & ne & $100^{a}$ & $83^{b}$ & $0^{c}$ & $1000++$ & ne & ne & ne & ne & \\
\hline PNH-c & $\mathrm{P}$ & ne & $100^{a}$ & $0^{\mathrm{e}}$ & $0^{c}$ & $1000+$ & ne & ne & ne & ne & \\
\hline$\alpha$-Asarone & CS & & ne & $100^{\mathrm{a}}$ & $75^{b}$ & $500++$ & ne & ne & $66^{c}$ & $0^{b}$ & $>500$ \\
\hline $\mathrm{NC}$ & & $0^{b}$ & $0^{\mathrm{d}}$ & $0^{\mathrm{e}}$ & $0^{c}$ & & $0 \mathrm{c}$ & $0^{\mathrm{d}}$ & $0^{\mathrm{f}}$ & $0^{\mathrm{b}}$ & \\
\hline PC & & $100^{a}$ & $100^{a}$ & $100^{a}$ & $100^{a}$ & & $100^{a}$ & $100^{a}$ & $100^{a}$ & $100^{a}$ & \\
\hline
\end{tabular}

MDT: Mosannona depressa (stem bark); MDR: M. depressa (root bark); PCR: Parathesis cubana (root); PNH: Piper neesianum (leaves); -a, -b, -c: nomenclature of fractions related with the solvent used; NC: negative control (conidial suspension/RPMI: Roswell Park Memorial Institute medium); PC: positive control (prochloraz 0.11\%); E: ethanol; H: hexane; A: acetonitrile; P: precipitate; CS: commercial standard; ne: not evaluated; (++): fungicidal; $(+)$ : fungistatic. ${ }^{a, b, c, d}$ : Means with different letters within columns differ significantly (Tukey's test, $p<0.05$ ).

\subsection{Inhibitory Concentration ( $I C_{50}$ and $\left.I C_{95}\right)$}

The $\alpha$-asarone standard had the lowest $\mathrm{IC}_{50}$ and $\mathrm{IC}_{95}$ against both species, followed by the MDT-b fraction from $M$. depressa stem bark (Table 4). Interestingly, the $\mathrm{IC}_{50}$ and $\mathrm{IC}_{95}$ for the MDT-b fraction and $\alpha$-asarone were very similar against F. oxysporum (respectively, 472 and $539 \mu \mathrm{g} / \mathrm{mL}, \mathrm{MDT}-\mathrm{b}, 482$ and $526 \mu \mathrm{g} / \mathrm{mL}, \alpha$-asarone). Against F. equiseti, the $\mathrm{IC}_{50}$ and $\mathrm{IC}_{95}$ for the MDT-b and PNH-b fractions were both 462 and $526 \mu \mathrm{g} / \mathrm{mL}$, respectively, higher than for $\alpha$-asarone and similar to those for the EE from M. depressa stem bark. 
Table 4. $\mathrm{IC}_{50}$ and $\mathrm{IC}_{95}$ of active extracts and fractions from Mosannona depressa, Parathesis cubana, Piper neesianum and of the commercial standard $\alpha$-asarone against mycelial growth of Fusarium equiset $i$ strain FCHE and F. oxysporum strain FCHJ.

\begin{tabular}{cccccc}
\hline \multirow{2}{*}{ Source } & \multirow{2}{*}{ Extract/Fraction } & \multicolumn{2}{c}{ Fusarium equiseti } & \multicolumn{2}{c}{ Fusarium oxysporum } \\
\cline { 3 - 6 } & & IC $_{\mathbf{5 0}} \mathbf{( C I )}$ & $\mathbf{I C}_{\mathbf{9 5}} \mathbf{( C I )}$ & IC $_{\mathbf{5 0}} \mathbf{( C I )}$ & IC $_{\mathbf{9 5}} \mathbf{( C I )}$ \\
\hline \multirow{2}{*}{ M. depressa } & MDT & $468(455-477)$ & $545(534-561)$ & $944(889-965)$ & $1079(1051-1156)$ \\
& MDT-b & $462(412-476)$ & $526(515-562)$ & $472(432-483)$ & $539(524-596)$ \\
$\alpha$-asarone & CS & $236(216-244)$ & $269(259-289)$ & $482(459-494)$ & $526(521-582)$ \\
P. cubana & PCR & $788(545-984)$ & $866(638-1063)$ & $876(836-920)$ & $1494(1407-1602)$ \\
P. neesianum & PNH & $788(545-984)$ & $866(638-1063)$ & ne & ne \\
& PNH-b & $462(412-476)$ & $526(515-562)$ & ne & ne \\
\hline
\end{tabular}

CI: confidence interval; CS: commercial standard; MDT: Mosannona depressa (stem bark); PCR: Parathesis cubana (root); PNH: Piper neesianum (leaves); b: acetonitrile fraction; ne: not evaluated.

\subsection{Effect of Active Extracts from Mosannona depressa on Morphology of Fusarium Strains}

The SEM of the untreated strains (negative control) showed typical well-formed hyphae and microconidia (Figures 1A-D and 2A-D). After $96 \mathrm{~h}$ of exposure to $2000 \mu \mathrm{g} / \mathrm{mL}$ EE from M. depressa stem bark, F. equiseti had distorted hyphae, globular structures along the surface of the mycelium and contorted and dehydrated conidia (Figure 1E). Conidia of the same strain were similarly affected by $2000 \mu \mathrm{g} / \mathrm{mL}$ EE from M. depressa root bark (Figure 1F).

Exposure of F. oxysporum to EE from M. depressa stem bark at $2000 \mu \mathrm{g} / \mathrm{mL}$ also led to malformed hyphae and contorted, dehydrated microconidia (Figure 2E), while EE from $M$. depressa root bark at $2000 \mu \mathrm{g} / \mathrm{mL}$ induced dehydration and distortion of hyphae and dehydration of microconidia (Figure 2F).

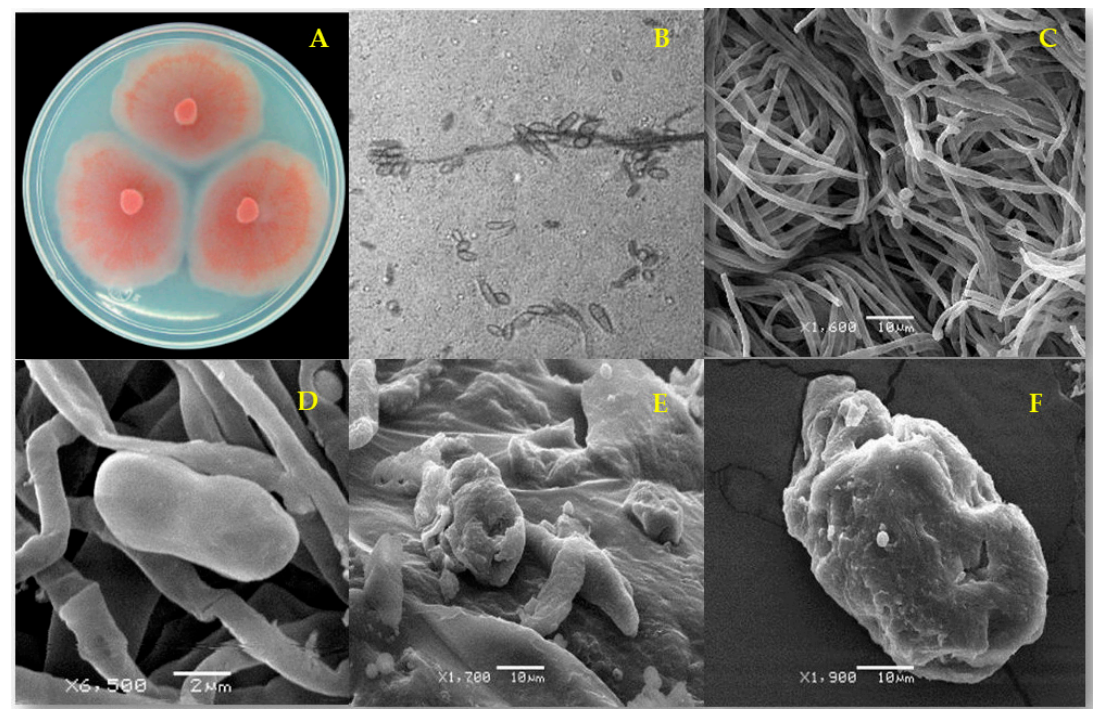

Figure 1. Fusarium equiseti strain FCHE morphology (A) after $7 \mathrm{~d}$ on potato dextrose agar; (B) microconidia of F. equiseti (1000X) and (C) typical untreated mycelium and microconidia (negative control); (D) apparently normal microconidium and (E) distorted mycelium and collapsed microconidia after $96 \mathrm{~h}$ treatment with ethanolic extract from Mosannona depressa stem bark at $2000 \mu \mathrm{g} / \mathrm{mL}$; (F) rough surface of a collapsed-looking microconidium after $96 \mathrm{~h}$ treatment with $2000 \mu \mathrm{g} / \mathrm{mL}$ ethanolic extract from $M$. depressa root bark. 


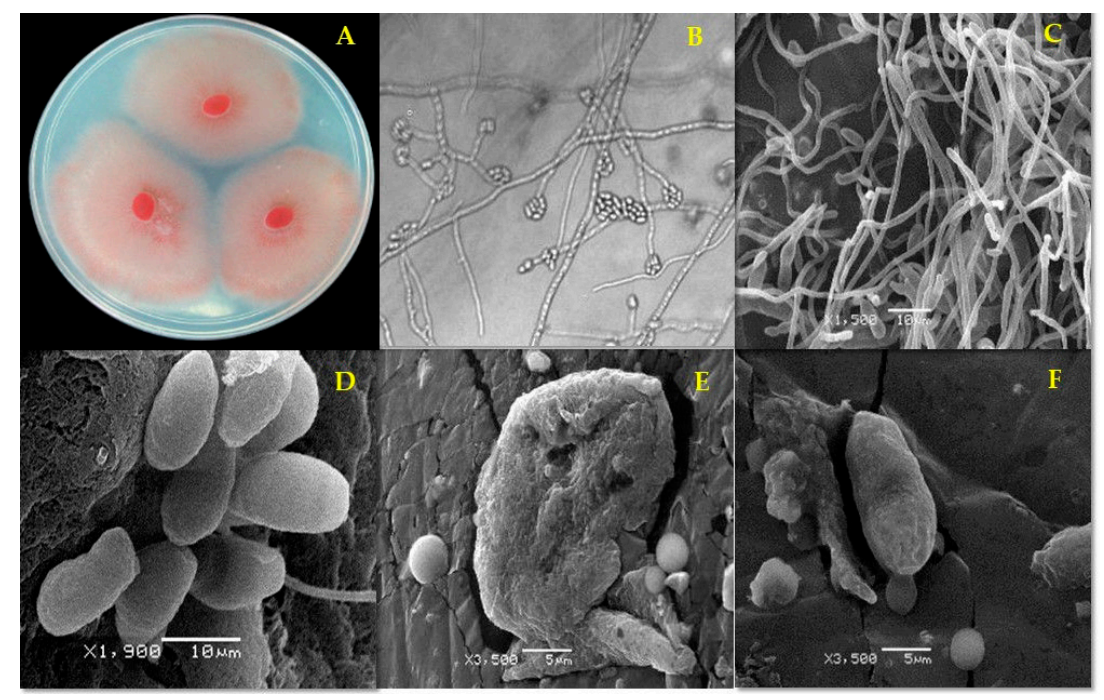

Figure 2. Fusarium oxysporum strain FCHJ morphology (A) after $7 \mathrm{~d}$ on potato dextrose agar (PDA). (B) Microconidia (1000X) and (C) typical mycelium and microconidia (negative control); (D) apparently normal microconidia, (E) misshapen and collapsed microconidium after $96 \mathrm{~h}$ treatment with ethanolic extract from Mosannona depressa stem bark at $2000 \mu \mathrm{g} / \mathrm{mL}$; (F) collapsed conidium after $96 \mathrm{~h}$ treatment with ethanolic extract from M. depressa root bark at $2000 \mu \mathrm{g} / \mathrm{mL}$.

\subsection{Identification of Active Components in Extracts from Mosannona depressa by LC-UV-HRMS}

The MDT-b and MDR-b fractions from M. depressa bark from the stem and roots were analyzed by LC-UV-HRMS (Table 5). The chromatogram of the MDT-b fraction showed five components, with the most abundant eluted at a retention time of $4.27 \mathrm{~min}$ (peak 3, Figure 3). The HRMS of peak 3 presented a protonated molecular ion at $m / z 209.1172$, indicative of a molecular formula of $\mathrm{C}_{12} \mathrm{H}_{16} \mathrm{O}_{3}$ (calc. for $\mathrm{C}_{12} \mathrm{H}_{17} \mathrm{O}_{3}{ }^{+}, 209.1173$ ), and its UV spectrum exhibited maxima at 220, 260 and $320 \mathrm{~nm}$. This component was identified as $\alpha$-asarone based on the reference spectrum in the equipment databases and confirmed using a commercial standard (Figure 3, Table 5). The minor components at retention times of 2.33, 2.55, 4.8 and $4.89 \mathrm{~min}$ had structural characteristics similar to those of $\alpha$-asarone, and their UV and HRMS data were compared with databases in the literature and Chapman \& Hall Dictionary of Natural Products (CHDNP). The HRMS of peak 1 showed UV maxima at 230 and $290 \mathrm{~nm}$, and a protonated ion at $m / z 225.1120$, suggesting a molecular formula of $\mathrm{C}_{12} \mathrm{H}_{16} \mathrm{O}_{4}$ (calc. for $\mathrm{C}_{12} \mathrm{H}_{17} \mathrm{O}_{4}{ }^{+}, 225.1121$ ), which was not assigned to any previously reported compound after comparison of the UV and HRMS data with databases in the literature and CHDNP. The analysis of peak 2 showed a protonated ion at $\mathrm{m} / \mathrm{z}$ of 197.0808 , with a molecular formula of $\mathrm{C}_{10} \mathrm{H}_{12} \mathrm{O}_{4}$ (calc. for $\mathrm{C}_{10} \mathrm{H}_{13} \mathrm{O}_{4}{ }^{+}, 197.0808$ ) and UV maxima at 238, 270 and $345 \mathrm{~nm}$; thus, the compound was tentatively identified as asaraldehyde. Components 4 and 5 had the same UV maxima at 220, 240 and $290 \mathrm{~nm}$ and protonated ions at $\mathrm{m} / \mathrm{z} 221.1170$ and 193.0857, respectively, accounting for molecular formulae of $\mathrm{C}_{13} \mathrm{H}_{16} \mathrm{O}_{3}$ (calc. for $\mathrm{C}_{13} \mathrm{H}_{17} \mathrm{O}_{3}{ }^{+}$, 221.1172) for component 4 and $\mathrm{C}_{11} \mathrm{H}_{12} \mathrm{O}_{3}$ (calc. for $\mathrm{C}_{11} \mathrm{H}_{13} \mathrm{O}_{3}{ }^{+}$, 193.0859) for component 5. After an exhaustive comparison of their spectral data with CHDPN and databases in the literature, compound 5 was tentatively identified as isomyristicin, but compound 4 was not identified (Table 5). 
Table 5. Metabolites identified from acetonitrile fraction of Mosannona depressa stem bark (MDT-b) by liquid chromatography-ultraviolet-high-resolution mass spectrometry (LC-UV-HRMS).

\begin{tabular}{cccccc}
\hline Peak & Retention Time (min) & ${\mathbf{M}+\mathbf{H}]^{+}}^{+}$ & MW & Molecular Formula & Compound \\
\hline 1 & 2.23 & 225.1120 & 224.1120 & $\mathrm{C}_{12} \mathrm{H}_{16} \mathrm{O}_{4}$ & Not identified \\
2 & 2.55 & 197.0808 & 196.0735 & $\mathrm{C}_{10} \mathrm{H}_{12} \mathrm{O}_{4}$ & Asaraldehyde \\
3 & 4.27 & 209.1172 & 208.1099 & $\mathrm{C}_{12} \mathrm{H}_{16} \mathrm{O}_{3}$ & $\alpha$-Asarone \\
4 & 4.81 & 221.1170 & 220.1097 & $\mathrm{C}_{13} \mathrm{H}_{16} \mathrm{O}_{3}$ & Not identified \\
5 & 4.89 & 193.0857 & 192.0784 & $\mathrm{C}_{11} \mathrm{H}_{12} \mathrm{O}_{3}$ & Isomyristicin \\
\hline
\end{tabular}

MW: molecular weight.
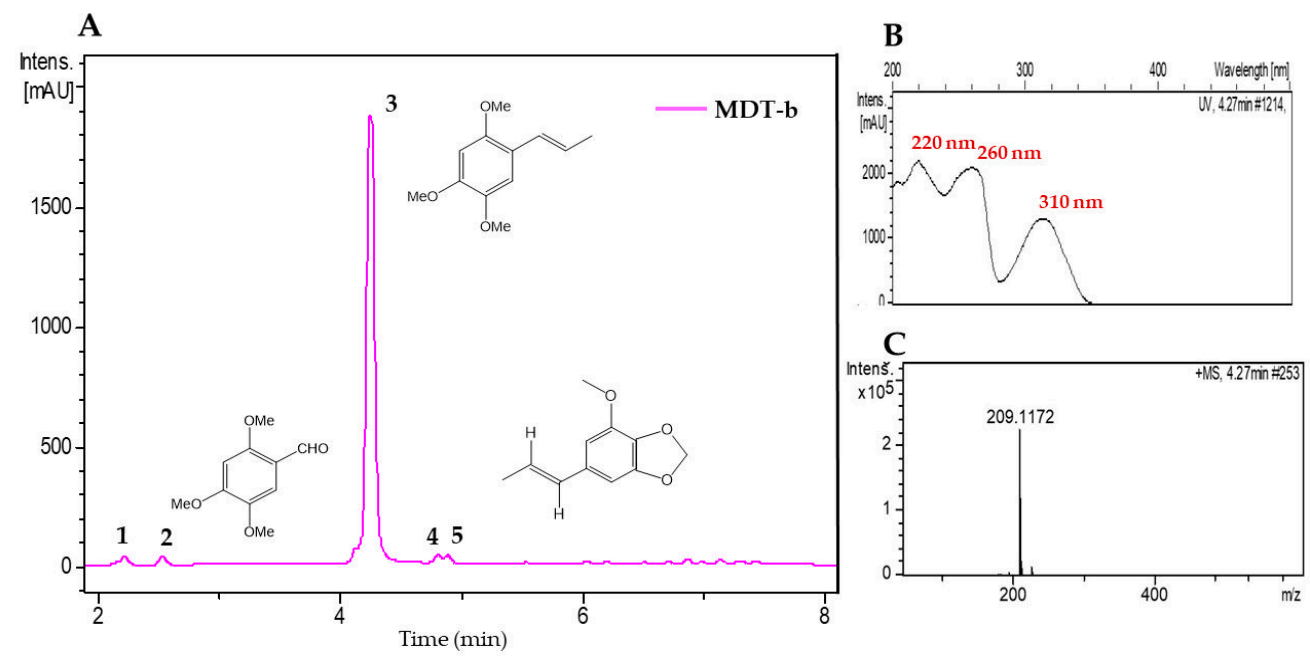

Figure 3. (A) Liquid chromatogram (UV $210 \mathrm{~nm}$ ) of acetonitrile fraction from stem bark of Mosannona depressa (MDT-b). 1: Not identified $\left(\mathrm{C}_{12} \mathrm{H}_{16} \mathrm{O}_{4}\right)$, 2: asaraldehyde, 3: $\alpha$-asarone, 4: not identified, 5: trans-isomyristicin. (B) UV spectrum of peak 3 and (C) high-resolution mass spectrum of peak 3.

Two components were detected in the medium polarity fraction (MDR-b) from $M$. depressa root bark (Figure 4). The most abundant was peak 2, with a retention time of $4.37 \mathrm{~min}$, showing a protonated ion at $m / z 239.1278$, with a molecular formula of $\mathrm{C}_{13} \mathrm{H}_{18} \mathrm{O}_{4}$ (calc. for $\mathrm{C}_{13} \mathrm{H}_{19} \mathrm{O}_{4}{ }^{+}$, 239.1278); its $\mathrm{UV}$ spectrum presented maxima at 205, 215 and $280 \mathrm{~nm}$. Comparison of these data with the databases led us to tentatively identify peak 2 as 1,2,3,4-tetramethoxy-5-(2-propenyl) benzene (Table 6). Data for peak 1 at a retention time of 4.25 min corresponded to $\alpha$-asarone (Table 6 ).

Table 6. Compounds identified in the acetonitrile fraction of the ethanolic extract of Mosannona depressa root bark (MDR-b) using LC-UV-HRMS.

\begin{tabular}{cccccc}
\hline Peak & Retention Time (min) & {$[\mathbf{M}+\mathbf{H}]^{+}$} & MW & Molecular Formula & Compound \\
\hline 1 & 4.25 & 209.1172 & 208.1094 & $\mathrm{C}_{12} \mathrm{H}_{16} \mathrm{O}_{3}$ & $\alpha$-Asarone \\
2 & 4.37 & 239.1278 & 238.1205 & $\mathrm{C}_{13} \mathrm{H}_{18} \mathrm{O}_{4}$ & 1,2,3,4-Tetramethoxy-5- (2-propenyl) benzene \\
\hline
\end{tabular}


A

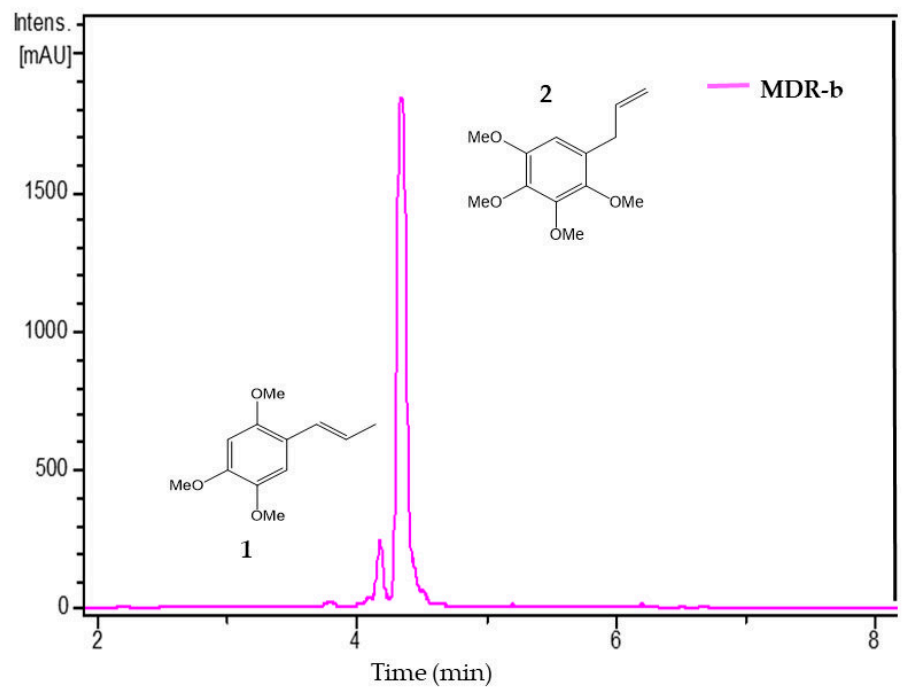

B

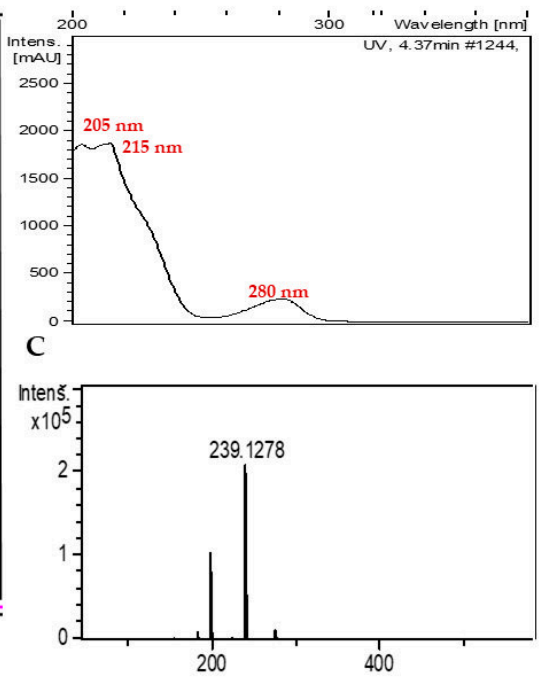

Figure 4. (A) Liquid chromatogram (UV at $210 \mathrm{~nm}$ ) of the acetonitrile fraction from Mosannona depressa root bark (MDR-b); 1: $\alpha$-asarone 2: 1,2,3,4-tetramethoxy-5-(2-propenyl) benzene. (B) UV spectrum of peak 2 and $(\mathbf{C})$ high-resolution mass spectra of peak 2.

\section{Discussion}

This first bioprospecting report on plant extracts with activity against fungal pathogens of habanero pepper is part of continuing efforts to discover potential bioactive compounds in the diverse flora of southeastern México. From sites not previously explored, we collected 40 plant species that our exhaustive search of the literature showed had not been tested against fungal phytopathogens, with the exception of Annona primigenia [28,29] and Mosannona depressa [30,31]. Antifungal screening of EEs and AEs from different vegetative parts of the 40 plant species led to the detection of six (15\% of the total) species with activity against the Fusarium strains tested. These active extracts were from Calea jamaicensis, Cameraria latifolia, Heteropterys laurifolia, Mosannona depressa, Parathesis cubana and Piper neesianum. Interestingly, these plant species belong to different families and were collected at the same site, Jahuactal, a tropical evergreen rainforest with trees exceeding $20 \mathrm{~m}$ in height.

Fusarium equiseti was more sensitive than F. oxysporum to the plant extracts tested. Mycelial growth of $F$. oxysporum was inhibited by only four EEs, representing $4.3 \%$ of the plant extracts tested, and totally insensitive to AEs at the tested concentration $(3 \% w / v)$. Several studies have indicated that AEs, even at higher concentrations, have limited effect on F. oxysporum. For example, the mycelial growth of F. oxysporum was inhibited $10-55 \%$ by extracts from leaves at $10 \%$ w/v of Ocimum sanctum [32] and stems, root and fruits of Momordica charantia [33], among others.

In contrast, in our study, four EEs completely inhibited the mycelial growth of both plant pathogens; the EEs from the bark of stems and roots of $M$. depressa were especially effective. Native to Mexico and Central America, this medicinal tree (syn. Annona depressa, Guatteria gaumeri, Malmea depressa and M. gaumeri) has a wide range of biological activities in humans, e.g., antifungal, antiproliferative, antiprotozoal, cytotoxic, hypoglycemic and hypocholesterolemic [34-36]. For agriculture applications, however, a chloroform extract from the stem bark of $M$. depressa was reported only as a growth inhibitor of Amaranthus hypochondriacus $\left(\mathrm{IC}_{50}=134 \mu \mathrm{g} / \mathrm{mL}\right)$ and Echinochloa crusgalli $\left(\mathrm{IC}_{50}=457 \mu \mathrm{g} / \mathrm{mL}\right)$, and as a fungicide against $F$. oxysporum (MIC $=400 \mu \mathrm{g} / \mathrm{mL}$ ) [31]; EEs from $M$. depressa stem and root bark had antifungal activity against Penicillium oxalicum (MIC $=250 \mu \mathrm{g} / \mathrm{mL}$ ) [37].

The present report is also the first on the fungicidal effect of the EEs from $M$. depressa against F. equiseti. The MIC of $1000 \mu \mathrm{g} / \mathrm{mL}$ for EEs from the bark of stems and roots of $M$. depressa is comparable to the effect against F. equiseti reported for ethanolic extracts of leaves from Calycopteris floribunda (MIC: $500 \mu \mathrm{g} / \mathrm{mL}$ ) [38] and rhizomes from Acorus calamus (MIC: $1000 \mu \mathrm{g} / \mathrm{mL}$ ) [39]. In the case of 
F. oxysporum, here, both EEs from the bark of stems and roots of $M$. depressa were fungistatic with a higher MIC of $2000 \mu \mathrm{g} / \mathrm{mL}$. In a previous study, a chloroform extract of the stem bark of $M$. depressa was antifungal against F. oxysporum (MIC: $400 \mu \mathrm{g} / \mathrm{mL}$ ) and Trichophyton mentagrophytes (MIC: $500 \mu \mathrm{g} / \mathrm{mL}$ ) [31]. The lower MIC may be attributed to the polarity of the solvent used and the susceptibility and forma specialis of the pathogenic strain tested [40]. Matos et al. [41] found variation in the sensitivity to Chelidonium majus extracts among six F. oxysporum isolates, with $\mathrm{f}$. $\mathrm{sp}$. cubense the most sensitive.

The guided fractionation with the antifungal assay of the EEs from the bark of stems and roots of $M$. depressa showed that $F$. equiseti and F. oxysporum were more sensitive to the MDT-b fraction. LC-UV-HRMS analyses revealed a mixture of phenylpropanoids in the MDT-b fraction; the major component was $\alpha$-asarone, with minor components asaraldehyde and isomyristicin, tentatively identified based on their UV and HRMS data. In the literature, we found only two phytochemical studies of an organic extract from $M$. depressa stem bark, which had a different metabolic profile [30,31]. Our results agree with the report by Enriquez et al. [30], who identified $\alpha$-asarone as the most abundant component in a hexane extract, which also included asaraldehyde, trans-isoelemicin and trans-isomyristicin. In the study by Jimenez Arellanes et al. [31], a chloroform extract contained four tetramethoxyl derivatives [1,2,3,4-tetramethoxy-5-(2-propenyl)-benzene, 2,3,4,5tetramethoxybenzaldehyde, 2,3,4,5-tetramethoxycinnamaldehyde, 2,3,4,5-tetramethoxycinnamyl alcohol] and trans-isomyristicin. Such differences in composition could be attributed to season, phenological stage and geographical region where plants were collected, which can greatly influence chemical biosynthesis and bioactivity. For example, essential oils from Perilla frutescens collected from 11 areas in China differed in yields and chemical composition, which were associated with antioxidant and antifungal activities [42]. When total alkaloids and the annomontine and oxopurpureine content from roots and leaves of Annona purpurea were monitored over time, the alkaloid was high during the dry season and during flowering; the strongest antifungal activity was obtained from the root extracts during the last month of the dry season [43].

In our investigation, $\alpha$-asarone (syn. trans-asarone) was identified as the principal compound responsible for the antifungal effect on F. equiseti and F. oxysporum. Its $\mathrm{IC}_{50}(236$ and $482 \mu \mathrm{g} / \mathrm{mL}$, respectively) and $\mathrm{IC}_{95}(269$ and $526 \mu \mathrm{g} / \mathrm{mL}$, respectively) were lower than those of the EE from $M$. depressa stem bark. An antifungal effect of $\alpha$-asarone at $1000 \mathrm{mg} / \mathrm{L}$ has been reported for the phytopathogens Phytophthora infestans and Pyricularia grisea with growth inhibition (GI) of 85 and 53\%, respectively [44], for Botrytis cinerea, F. oxysporum and Phomopsis obscurans (GI = 57.7, 43.6 and 41.5\%, respectively) at $300 \mu \mathrm{M}$ [45] and slight activity against the yeasts Candida albicans, C. kruseii and C. parapsilasis at $100 \mu \mathrm{g} / \mathrm{mL}$ [46]. It also has pesticidal properties as an antifeedant against Helicovarpa zea, Helionthis virescens and Manduca sexta; it is insecticidal against Aedes aegypti and Lucila sericata, and nematocidal against Caenorhabditis elegans, Panagrellus redivivus and Nyppostrongylus brasiliensis [46,47]. Interestingly, Jimenez Arellanes et al. [31] reported that 1,2,3,4-tetramethoxy-5-(2-propenyl)-benzene was the most abundant component in the chloroform extract ( $0.71 \%$ from dried stem bark) and the major phytogrowth inhibitory compound in Amaranthus hychondriacus ( $\left.\mathrm{IC}_{50}=43 \mu \mathrm{g} / \mathrm{mL}\right)$ and E. crusgalli $\left(\mathrm{IC}_{50}=43 \mu \mathrm{g} / \mathrm{mL}\right)$, and it had an antifungal effect on an undocumented strain of F. oxysporum (MIC: $250 \mu \mathrm{g} / \mathrm{mL}$ ). In the present study, this compound was not detected from the stem extracts. However, it was abundant in the MDR-b fraction from $M$. depressa root bark, but it had no effect on the mycelial growth of F. oxysporum strain FCHJ, and F. equiseti strain FCHE was only moderately sensitive (75\% MGI at $1000 \mu \mathrm{g} / \mathrm{mL}$ ). Based on these results, the antifungal activity of $M$. depressa collected in Jahuactal is considered to be primarily due to the presence of $\alpha$-asarone in the extract.

As shown by SEM, EE from M. depressa stem bark at $2000 \mu \mathrm{g} / \mathrm{mL}$ caused prominent morphological alterations of F. oxysporum and F. equiseti. Hyphae were malformed and contorted, and microconidia had collapsed. This effect is similar to the morphological changes in conidia and hyphae of the filamentous zoopathogenic fungus Microsporum gyseum after $4 \mathrm{~d}$ exposure to $100 \mathrm{mg} / \mathrm{mL}$ of the $\beta$-asarone fraction [48]; further cell death of F. oxysporum induced by a mixture of asarones $(\alpha, \beta, \gamma$, 3.4:94.3:1\%) at $500 \mu \mathrm{g} / \mathrm{mL}$ was observed using epifluorescence microscopy; the rapid cell death is 
correlated with greater production of reactive oxygen species [49]. Studies on the mechanism of action of $\beta$-asarone showed that it interferes with ergosterol synthesis, thus the ergosterol content is lowered in the plasma membrane of Aspergillus niger ATCC 16,888 [50], confirming that the effect against F. oxysporum might be related to the inhibition of ergosterol biosynthesis, as it is in C. albicans [51]. Hence, similar to its isomer $\beta$-asarone, $\alpha$-asarone in the EE from $M$. depressa stem bark might inhibit the mycelial growth of F. oxysporum and F. equiseti by damaging the plasma membrane and causing cell death. More studies are needed to verify the site of action of asarones and other metabolites of M. depressa on fungal pathogens.

Another promising plant species for antifungal compounds in our study was P. neesianum (Piperaceae, syn. Piper sempervirens, Arctottonia sempervirens), a tree used in traditional medicine to treat snake bites and wounds $[52,53]$. The EE from $P$. neesianum leaves and its $\mathrm{PNH}-\mathrm{b}$ fraction completely inhibited the growth of F. equiseti (MIC: $1000 \mu \mathrm{g} / \mathrm{mL}$ ) and had the same $\mathrm{IC}_{50}$ and $\mathrm{IC}_{95}$ (462 and $866 \mu \mathrm{g} / \mathrm{mL}$, respectively) as the MDT-b fraction. This report is the first of an antifungal effect of P. neesianum against F. equiseti and F. oxysporum. The dichloromethane extract from leaves of $P$. neesianum has been reported to have various biological activities as an antioxidant ( $\left.\mathrm{IC}_{50}=\mathrm{DPPH} 0.071 \mathrm{mg} / \mathrm{mL}\right)$ [54], anti-tyrosinase $\left(\mathrm{IC}_{50}=6.6 \mu \mathrm{g} / \mathrm{mL}\right.$ [55] and anti-urease $\left(\mathrm{IC}_{50}=12.9 \mu \mathrm{g} / \mathrm{mL}\right)$ [56]. Essential oil from P. neesianum leaves collected in the northern region of Guatemala contained bicyclogermacrene $(28 \%)$, germacrene D $(11.7 \%)$ and $\beta$-caryopyllene $(7.5 \%)$ as major compounds among 19 detected in a gas chromatography with flame ionization detection- mass spectrometry analysis [52].

The EE from P. cubana (Primulaceae; syn. Ardisia cubana) roots was also active against both Fusarium pathogens, and the low polarity PCR-a fraction was fungicidal (MIC: $1000 \mu \mathrm{g} / \mathrm{mL}$ ). These findings are the first report of a biological activity for extracts from P. cubana.

The EA from C. jamaicensis (Asteraceae) was the only EA that moderately inhibited the growth of F. equiseti, suggesting that it produces a highly polar antifungal metabolite(s). This species was documented to have leishmanicidal activity and to be useful for treating colds and stomach pain $[57,58]$, but the present report is the first on its antifungal activity. Among 125 Calea species, only C. urticifolia has been tested against fungal pathogens, but it had no activity against F. oxysporum [25,59]. Acacetin, O-methylacacetin, jamaicolides A-D and prumichromene B have been identified in aerial parts of C. jamaicensis [58].

In summary, the present investigation revealed that F. equiseti FCHE and F. oxysporum FCHJ strains isolated from habanero pepper plants were sensitive to extracts from six native plant species, and the most effective were the EEs from $M$. depressa, P. cubana and P. neesianum, and advanced our knowledge about the phytochemicals in the roots of $M$. depressa from the Yucatán Peninsula. $\alpha$-Asarone was identified as the principal antifungal component in the stem bark of $M$. depressa. Now, we need to determine the persistence of its antifungal effect and any toxicity to the environment and beneficial macro- and microorganisms in the soil as a pure compound and in the complex ethanolic extract mixture.

Our knowledge on the pesticidal potential of the native Mexican flora has also been enriched, and on the basis of our broad screening, we will isolate and identify the compounds in the active EEs from P. cubana and P. neesianum and the AE from C. jamaicensis that contribute to the antifungal activity. Subsequently, we expect to propagate the promising species to provide material for greenhouse and field experiments. Of course, the mechanism and sites of action of the identified metabolites in the fungus need to be determined, and the metabolites tested for safety against nontarget organisms. This research also opens opportunities for future studies on the conservation and sustainable use of our regional flora in the development of biorational products for the integrated management of $C$. chinense and other species of Capsicum. 


\section{Materials and Methods}

\subsection{Plant Materials}

Plants were collected from six locations in the Yucatán Peninsula: (1) Jahuactal, Ejido Caobas, Othón Pompeyo Blanco $\left(18^{\circ} 15^{\prime} 34^{\prime \prime} \mathrm{N}, 88^{\circ} 57^{\prime} 14^{\prime \prime} \mathrm{W}\right)$, (2) Kaxil Kiuic, Oxkutzcab $\left(20^{\circ} 06^{\prime} 10.8^{\prime \prime}\right.$ N;

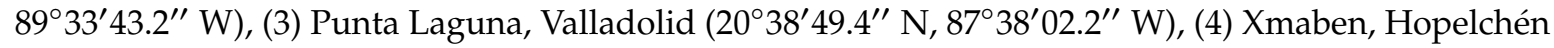

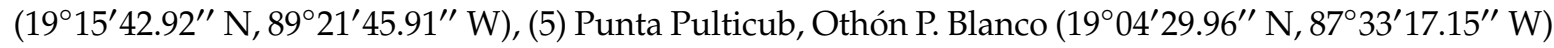
and (6) Chacchoben Limones, Othón P. Blanco $\left(19^{\circ} 01^{\prime} 44.31^{\prime \prime} \mathrm{N}, 88^{\circ} 08^{\prime} 00.38^{\prime \prime} \mathrm{W}\right)$ of the states of Yucatán and Quintana Roo (Table 1). Each plant was separated into leaves, stems and roots for separate extractions, and whole plants (WP) of some species were extracted. Plant materials were dried in a lamp stove at 55-60 ${ }^{\circ} \mathrm{C}$ for $5 \mathrm{~d}$ and crushed in a mill (model 1520, Pagani, Azcapotzalco, México) with blades and no. $5 \mathrm{~mm}$ mesh. A voucher specimen for each plant species was deposited in the Roger Orellana Herbarium of the Unidad de Recursos Naturales del Centro de Investigación Científica de Yucatán and identified by experts (Table 1).

\subsection{Preparation of Plant Extracts}

\subsubsection{Aqueous Extracts}

The dried, ground plant material $(1.5 \mathrm{~g})$ was transferred to an Erlenmeyer flask, and $20 \mathrm{~mL}$ of boiling distilled water were added. After $15 \mathrm{~min}$, the sample was filtered through filter paper (Whatman no. 1) and cotton to remove solid residues, then diluted with distilled water to $25 \mathrm{~mL}$, to obtain an aqueous extract (AE) with a final concentration of $6 \%(w / v)$. Under aseptic conditions, the infusion was sterilized using a $0.22 \mu \mathrm{m}$ Millipore filter (Merck-Millipore, Burlington, MA, USA), and frozen at $-17.5 \pm 0.5^{\circ} \mathrm{C}$ until use [60].

\subsubsection{Ethanolic Extracts}

The dried, ground plant material was immersed in ethanol (1.5\% of the total volume) and extracted three times with ethanol by sonication at $20 \mathrm{kHz}$ (Cole-Parmer, Chicago, IL, USA), at room temperature for $20 \mathrm{~min}$ each time. The solvent was filtered and eliminated under vacuum in a rotary evaporator (IKA model RV-10, Staufen, Germany) at $40{ }^{\circ} \mathrm{C}$ to obtain the ethanolic crude extract [24]. The EEs with the greatest activity in the antifungal assay described (Section 4.4) were partitioned with hexane-acetonitrile three times (2: $1,1: 1,1: 1 v / v)$ and solvents removed as described above. In this way, a hexane fraction (A), acetonitrile fraction (B) and methanol-soluble precipitate (C) of each EE were obtained.

\subsection{Fungal Cultures}

Phytopathogenic strains of Fusarium equiseti (FCHE, GenBank acc. MG020433) and F. oxysporum (FCHJ, GenBank acc. MG020428) were obtained from the fungal collection of the Phytopathology Laboratory, Tecnológico Nacional de México, Instituto Tecnológico de Conkal. These strains were isolated from stem and root lesions of habanero pepper plants [10]. The strains were maintained by transferring a mycelial disc (5 mm diameter) to (a) $20 \%$ glycerol $(v / v)$ and frozen at $-80{ }^{\circ} \mathrm{C},(\mathrm{b})$ sterile distilled water and (c) commercial potato dextrose agar in slant tubes (PDA, BD, Bioxon, Edo. México) and stored at $4^{\circ} \mathrm{C}$ in the dark.

\subsection{Antifungal Microdilution Assay of Extracts}

\subsubsection{Preparation of Conidial Suspension}

F. equiseti and F. oxysporum strains were reactivated on PDA and incubated at $27 \pm 2{ }^{\circ} \mathrm{C}$, with $16 \mathrm{~h}$ light/8 h dark in a humidity chamber to induce sporulation. After 7 days, the surface of the culture was flooded with a sterile saline solution $(5 \mathrm{~mL})$, then gently scraped with a sterile brush to release 
conidia into the saline. The resulting conidial suspension was filtered through a double layer of sterile cheesecloth and adjusted to a final concentration of $1 \times 10^{5}$ conidia/mL for both pathogens with sterile saline solution, using a hemocytometer [61].

\subsubsection{Bioassay with Aqueous Extracts}

In the broth microdilution to determine the mycelial growth inhibition (MGI) of the Fusarium strains, $100 \mu \mathrm{L}$ of each $6 \%$ AE were transferred to each microwell of a 96-well plate. As a negative control, $100 \mu \mathrm{L}$ of the conidial suspension were used and as positive control, $5 \mu \mathrm{L}$ of the fungicide Mirage CE 45 (prochloraz $450 \mathrm{~g}$ a.i./L) (Bayer CropScience, NC, USA). Finally, $100 \mu \mathrm{L}$ of the conidial suspension were added for a final concentration of $3 \% w / v$ AE, $0.112 \%$ of prochloraz $(w / v), 5 \times 10^{4}$ conidia $/ \mathrm{mL}$ of Fusarium strains. All tests were performed in triplicate and microdilution plates maintained at $27 \pm 2{ }^{\circ} \mathrm{C}$, and $16 \mathrm{~h}$ light $/ 8 \mathrm{~h}$ dark. The $\mathrm{MG}$ was recorded at $96 \mathrm{~h}$, visually determined with a microscope at $50 \times$ using the National Committee for Clinical Laboratory Standards with slight modifications, using a $0-4$ scale, where 4 is full MG (0\% MGI) and 0 the absence of MG (MGI $=100 \%)[62,63]$. Data were converted to a percentage of mycelial growth inhibition (MGI) using Abbott's formula: [(\% MG in the negative control - \% MG in the treatment)/\% MG in the negative control)] $\times 100$ [62].

\subsubsection{Bioassay with Ethanolic Extracts}

Each EE was dissolved in a mixture of dimethylsulfoxide (DMSO) (Sigma-Aldrich, St. Louis, MO, USA) with $0.5 \%$ Tween 20 to obtain a solution at $40 \mu \mathrm{g} / \mu \mathrm{L}$ EE. Then $10 \mu \mathrm{L}$ of this EE solution were added to each microwell, containing $90 \mu \mathrm{L}$ of RPMI liquid medium (Roswell Park Memorial Institute 1640). Mirage CE $45(5 \mu \mathrm{L})$ was used as the positive control as described above; negative growth controls were RMPI (Merck Millipore Darmstadt, Germany), water $(100 \mu \mathrm{L})$ and a blank $(0.5 \%$ Tween 20 DMSO: RPMI 1:9, v/v). Each microwell then received $100 \mu \mathrm{L}$ of the conidial suspension for a final EE concentration of $2000 \mu \mathrm{g} / \mathrm{mL}$ and 5\% of DMSO with $0.5 \%$ Tween 20 (Merck Millipore Darmstadt, Germany) [24]. All tests were done three times, and the plates were incubated and assessed as described above.

\subsubsection{Minimum Inhibitory Concentration of Active EEs and Fractions}

Serial dilutions of fractions A, B and C and active EE solutions $(80 \mu \mathrm{g} / \mu \mathrm{L})$, prepared as described above, were evaluated in a microdilution assay to determine the MIC [24]. The EEs were tested at final concentrations of 2000, 1000, 500 and $250 \mu \mathrm{g} / \mathrm{mL}$. The fractions were evaluated at 1000, 500 and $250 \mu \mathrm{g} / \mathrm{mL}$. The commercial $\alpha$-asarone standard (Sigma-Aldrich, St. Louis, MO, USA) was tested at 500, 250 and $125 \mu \mathrm{g} / \mathrm{mL}$. The same controls and incubation conditions were used as described above. All determinations were made with four replicates, three times. After incubation at $96 \mathrm{~h}$, the MIC was determined as the lowest concentration of the extract at which no mycelial growth was observed in the well.

After $96 \mathrm{~h}$ of incubation, $10 \mu \mathrm{L}$ from each well that had no growth were transferred to PDA and incubated at $27 \pm 2{ }^{\circ} \mathrm{C}$. After $72 \mathrm{~h}$, the presence of growth was cataloged as fungicidal, the absence of growth as fungistatic [64].

\subsection{Effect of Ethanolic Extracts on Hyphal Morphology of Fusarium Strains}

The strains of F. equiseti and F. oxysporum were grown on PDA in Petri dishes for $7 \mathrm{~d}$, then $5 \mathrm{~mm}$ disks were removed from the growing edge of the colony. The samples were fixed in $2.5 \% \mathrm{v} / \mathrm{v}$ glutaraldehyde (Merck Millipore Darmstadt, Germany) and 0.2 M sodium phosphate (Sigma-Aldrich, St. Louis, MO, USA) pH 7.2 for $48 \mathrm{~h}$ at $4{ }^{\circ} \mathrm{C}$ and washed twice with the phosphate buffer ( $1 \mathrm{~h}$ each time). The samples were dehydrated in an ethanol series ( $1 \mathrm{~h}$ each: 30, 50, 70, 85, 96 and 100\%, $2 \times$ absolute ethanol). The samples were dried with $\mathrm{CO}_{2}$ in a Sandri-795 critical point dryer (Tousimis Research Corp., Rockville, MD, USA), then attached to a sample holder using double-sided adhesive carbon 
tape and coated with gold for $10 \mathrm{~min}$ in an ionizing chamber (Dentom Vacuum-Desk II, Moorestown, NJ, USA). The samples were observed in a JSM 6360 SEM (Jeol, Tokyo, Japan) at $20 \mathrm{kV}$.

After the fungus was exposed for $96 \mathrm{~h}$ to $200 \mu \mathrm{L}$ of EE from M. depressa, the mixture was filtered through a nylon membrane (nucleic acid blotting membrane Hybond $\mathrm{N}^{+} 0.45 \mu \mathrm{m}$ ) (GE Healthcare Bioscience, Amersham PI, Little Chalfont, UK), and the fungal samples were fixed as described above.

\subsection{Chromatographic and Spectrometric Analyses}

\subsubsection{Thin Layer Chromatography (TLC)}

The active EEs and their fractions were analyzed by thin layer chromatography (TLC) using an aluminum support impregnated with $0.25 \mathrm{~mm}$ thick G-60 silica gel with fluorescent indicator $\mathrm{F}_{254}$ (Merck Millipore, Burlington, MA, USA). In parallel, the commercial standard $\alpha$-asarone (Sigma-Aldrich, St. Louis, MO, USA) was applied to confirm its presence in $M$. depressa extracts. The plates were developed in three elution systems: hexane-acetone (8:2), $\mathrm{CH}_{2} \mathrm{Cl}_{2}$-AcOEt (9:1) and $\mathrm{CH}_{2} \mathrm{Cl}_{2}-\mathrm{MeOH}$ (85:15). After separation, the metabolites were visualized with ultraviolet light $\left(\mathrm{UV}_{254}\right.$ and $\left.\mathrm{UV}_{365}\right)$ and phosphomolybdic acid (Sigma-Aldrich, St. Louis, MO, USA).

\subsubsection{LC-UV-HRMS}

The active fractions $(2 \mu \mathrm{L})$ from $M$. depressa stem bark (MDT-b) and root bark (MDR-b) were analyzed by liquid chromatography-ultraviolet-high-resolution mass spectrometry (LC-UV-HRMS) using a data-dependent acquisition protocol [65]. Chromatograms and mass spectra were obtained using an LC-MS (Agilent, Santa Clara, CA, USA) coupled to a Bruker Maxis HR-QTOF mass detector (Bruker Daltonics $\mathrm{GmbH}$, Bremen, Germany) at $40^{\circ} \mathrm{C}$. A Zorbax SB-C8 column (Agilent, Santa Clara, CA, USA) was used $(2.1 \times 30 \mathrm{~mm})$ with a mobile phase of a mixture of solvent $A$ (water-acetonitrile 90:10 with $0.01 \% v / v$ trifluoroacetic acid and $1.3 \mathrm{mM}$ ammonium formate) and solvent $\mathrm{B}$ (water-acetonitrile $10: 90$ with $0.01 \% v / v$ trifluoroacetic acid and $1.3 \mathrm{mM}$ ammonium formate) and a flow rate of $300 \mu \mathrm{L} / \mathrm{min}$. The gradient was set for a constant flow rate of $10 \%$ B to $100 \%$ B in $6 \mathrm{~min}, 100 \%$ B for $2 \mathrm{~min}$, then $10 \%$ B for $2 \mathrm{~min}$. Mass spectra (150 to $2000 \mathrm{~m} / \mathrm{z}$ ) were acquired in positive mode. The components detected were compared with the MEDINA database of microbial metabolites and the Chapman \& Hall Dictionary of Natural Products (v25.1, CRC Press, Boca Raton, FL, USA).

\subsection{Statistical Analyses}

For the \% MGI data, a one-way analysis of variance was performed with prior transformation of the original data using the formula: $y=\operatorname{arsin}[\operatorname{sqrt}(y / 100)]$. The treatment means were compared using Tukey's multiple range test $(p=0.05)$. Variance analyses were performed using SAS ver. 9.4 for Windows (SAS Institute, Cary, NC, USA). IC 50 and IC 95 values with $95 \%$ confidence intervals were calculated for EEs and effective fractions using a probit analysis.

Supplementary Materials: The following are available online at http://www.mdpi.com/2076-0817/9/10/827/s1, Table S1: Inhibition of mycelial growth of Fusarium equiseti strain FCHE and F. oxysporum strain FCHJ by plant extracts from 40 native species of the Yucatán Peninsula in microdilution assay.

Author Contributions: M.G.-A and J.C.-A. conceived the project; P.C.-C. performed the experiments, collected and analyzed data and wrote the original draft; J.M. and F.R. carried out LC-UV-HRMS data acquisition, analysis and interpretation; V.R.-C. and M.V.-K. reviewed the manuscript; G.C. collected and identified the plants. J.C.-A and M.G.-A. supervised and provided biological material for assays. All authors participated in the interpretation of the data, reviewed and approved the final version of the submitted manuscript. All authors have read and agreed to the published version of the manuscript.

Funding: This research was financially supported by CONACYT project PDCPN-2015-266. P.C.-C. thanks CONACYT for a doctoral student scholarship (No. 661906).

Acknowledgments: P.C.-C. thanks the Instituto Tecnológico Nacional de México, Campus Conkal. Mérida, Yucatán, José Luis Tapia Muñoz., Jesus Aviles Gómez, I. Leticia Medina Baizabal, and Felipe Barredo for greatly appreciated technical assistance. 
Conflicts of Interest: The authors declare no conflict of interest.

\section{References}

1. Dean, R.; Van Kan, J.A.L.; Pretorius, Z.A.; Hammond-Kosack, K.E.; Di Pietro, A.; Spanu, P.D.; Rudd, J.J.; Dickman, M.; Kajmann, R.; Ellis, J.; et al. The top 10 fungal pathogens in molecular plant pathology. Mol. Plant. Pathol. 2012, 13, 414-430. [CrossRef]

2. Velarde-Félix, S.; Garzón-Tiznado, J.A.; Hernández-Verdugo, S.; López-Orona, C.A.; Retes-Manjarrez, J.E. Occurrence of Fusarium oxysporum causing wilt on pepper in México. Can. J. Plant. Pathol. 2018, 40, 238-247. [CrossRef]

3. Bosland, P.W.; Votava, E.J. Peppers: Vegetable and Spice Capsicums, 2nd ed.; CABI: Wallingford, Oxfordshire, UK, 2012; Volume 22, pp. 16-36, ISBN 9781845938253.

4. Naves, E.R.; de Ávila Silva, L.; Sulpice, R.; Araújo, W.L.; Nunes-Nesi, A.; Pérez, L.E.; Zsögön, A. Capsaicinoids: Pungency beyond. Capsicum. Trends Plant. Sci. 2019, 24, 109-120. [CrossRef]

5. Chiles y Pimientos. Available online: https://www.gob.mx/cms/uploads/attachment/file/255626/Planeaci_n_ Agr_cola_Nacional_2017-2030__parte_tres (accessed on 14 September 2020).

6. Srinivasan, K. Biological activities of red pepper (Capsicum annuum) and its pungent principle capsaicin: A review. Crit. Rev. Food Sci. Nutr. 2015, 56, 1488-1500. [CrossRef] [PubMed]

7. Ruiz-Lau, N.; Medina-Lara, F.; Martínez-Estévez, M. El chile habanero: Su origen y usos. Ciencia 2011, 63, 70-77.

8. Anuario Estadístico de la Producción Agrícola. Available online: https://nube.siap.gob.mx/cierreagricola (accessed on 14 September 2020).

9. Mejía-Bautista, M.Á.; Reyes-Ramírez, A.; Cristóbal-Alejo, J.; Tun-Suárez, J.M.; Borges-Gómez, L.D.C.; Pacheco-Aguilar, J.R. Bacillus spp. en el control de la marchitez causada por Fusarium spp. en Capsicum chinense. Rev. Mex. Fitopatol. 2016, 34, 208-222. [CrossRef]

10. Mis-Mut, D.M. Identificación Molecular de Trichoderma spp. con Aplicación Agrícola y su Efectividad in vitro Contra Fusarium spp. Tesis de Maestría; Instituto Tecnológico de Conkal: Mérida, Yucatán, Mexico, 2015.

11. Shi, W.; Tan, Y.; Wang, S.; Gardiner, D.M.; De Saeger, A.; Liao, Y.; Wang, C.; Fan, Y.; Wang, Z.; Wu, A. Mycotoxigenic potentials of Fusarium species in various culture matrices revealed by mycotoxin profiling. Toxins 2017, 9, 6. [CrossRef]

12. Bashir, M.R.; Atiq, M.; Sajid, M.; Mohsan, M.; Abbas, W.; Alam, M.W.; Bashair, M. Antifungal exploitation of fungicides against Fusarium oxysporum f. sp. capsici causing Fusarium wilt of chilli pepper in Pakistan. Environ. Sci. Pollut. Res. 2018, 25, 6797-6801. [CrossRef]

13. Carvalho, F.P. Pesticides, environment, and food safety. Food Energ. Sec. 2017, 6, 48-60. [CrossRef]

14. Gaherwal, S.; Prakash, M.M.; Khasdeo, K.; Sharma, A. Impact of selected chemical and herbal pesticide on beneficial soil microorganism. Int. J. Microbiol. Res. 2015, 6, 236-239. [CrossRef]

15. Matyjaszczyk, E. "Biorationals" in integrated pest management strategies. J. Plant. Dis. Prot. 2018, 125, 523-527. [CrossRef]

16. Moya-Elizondo, E.A.; Jacobsen, B.J. Integrated management of Fusarium crown rot of wheat using fungicide seed treatment, cultivar resistance, and induction of systemic acquired resistance (SAR). Biol. Control. 2016, 92, 153-163. [CrossRef]

17. Walia, S.; Saha, S.; Tripathi, V.; Sharma, K.K. Phytochemical biopesticides: Some recent developments. Phytochem. Rev. 2017, 16, 989-1007. [CrossRef]

18. Ramírez-Mares, M.V.; Hernández-Carlos, B. Plant-derived natural products from the American continent for the control of phytopathogenic fungi: A review. J. Glob. Innov. Agric. Soc. Sci. 2015, 3, 96-118. [CrossRef]

19. Peñuelas-Rubio, O.; Arellano-Gil, M.; Verdugo-Fuentes, A.A.; Chaparro-Encinas, L.A.; Hernández-Rodríguez, S.E.; Martínez-Carrillo, J.L.; Vargas-Arispuro, I.D.C. Larrea tridentata extracts as an ecological strategy against Fusarium oxysporum radicis-lycopersici in tomato plants under greenhouse conditions. Rev. Mex. Fitopatol. 2017, 35, 360-376. [CrossRef]

20. Sesan, T.E.; Enache, E.; Iacomi, B.M.; Oprea, M.; Oancea, F.; Iacomi, C. In vitro antifungal activity of some plant extracts against Fusarium oxysporum in blackcurrant (Ribes nigrum L.). Acta Sci. Pol. Hortorum Cultus. 2017, 16, 163-172. [CrossRef] 
21. De Rodríguez, D.J.; Trejo-González, F.A.; Rodríguez-García, R.; Díaz-Jimenez, M.L.V.; Sáenz-Galindo, A.; Hernández-Castillo, F.D.; Peña-Ramos, F.M. Antifungal activity in vitro of Rhus muelleri against Fusarium oxysporum f. sp. lycopersici. Ind. Crops Prod. 2015, 75, 150-158. [CrossRef]

22. Villaseñor, J.L. Checklist of the native vascular plants of México. Rev. Mex. Biodivers. 2016, 87, 559-902. [CrossRef]

23. Ramírez-Morillo, I.M. La flora de la península de Yucatán: ¿Diversa? ¿Bien conocida? ¿Protegida? No, no y ¿No? Desde Herb. CICY 2019, 11, 130-137.

24. Vargas-Díaz, A.A.; Gamboa Angulo, M.; Medina Baizabal, I.L.; Pérez Brito, D.; Cristóbal Alejo, J.; Ruiz Sánchez, E. Evaluation of native Yucatecan plant extracts against Alternaria chrysanthemi and antifungal spectrum of Acalypha gaumeri. Rev. Mex. Fitopatol. 2014, 32, 01-11.

25. Gamboa-Angulo, M.M.; Cristóbal-Alejo, J.; Medina-Baizabal, I.L.; Chí-Romero, F.; Méndez-González, R.; Simá-Polanco, P.; May-Pat, F. Antifungal properties of selected plants from the Yucatan peninsula, Mexico. World J. Microbiol. Biotechnol. 2008, 24, 1955-1959. [CrossRef]

26. Peraza-Sánchez, S.R.; Chan-Che, E.O.; Ruiz-Sánchez, E. Screening of Yucatecan plant extracts to control Colletotrichum gloeosporioides and isolation of a new pimarene from Acacia pennatula. J. Agric. Food Chem. 2005, 53, 2429-2432. [CrossRef] [PubMed]

27. Digital Flora: Península de Yucatán, Herbario CICY, Unidad de Recursos Naturales. Available online: http://www.cicy.mx/sitios/flora\%20digital/ficha_virtual.php? especie=820 (accessed on 21 May 2020).

28. Baños, S.B.; Necha, L.L.B.; Luna, L.B.; Torres, K.B. Antifungal activity of leaf and stem extracts from various plant species on the incidence of Colletotrichum gloeosporioides of papaya and mango fruit after storage. Rev. Mex. Fitopatol. 2002, 20, 8-12.

29. Mogle, U.P. Efficacy of leaf extracts against the post-harvest fungal pathogens of cowpea. Biosci. Discov. 2013, 4, 39-42.

30. Enríquez, R.G.; Chávez, M.A.; Jauregui, F. Propenylbenzenes from Guatteria gaumeri. Phytochemistry 1980, 19, 2024-2025. [CrossRef]

31. Jimenez Arellanes, A.; Mata, R.; Lotina-Henssen, B.; Lang, A.L.A.; Ibarra, L.V. Phytogrowth-inhibitory compounds from Malmea depressa. J. Nat. Prod. 1996, 59, 202-204. [CrossRef]

32. Sharma, S.; Singh, R.; Thakre, B. Antifungal activity of leaf extracts of Ocimum sanctum against fungal pathogens. Int. J. Curr. Microbiol. Appl. Sci. 2019, 8, 1210-1214. [CrossRef]

33. Gupta, M.; Sharma, S.; Bhadauria, R. In vitro efficacy of Momordica charantia extracts against phytopathogenic fungi, Fusarium oxysporum. J. Biopest. 2016, 9, 8-22.

34. Mejía, R. Guatteria gaumeri, Malmea depressa o Yumel, una revisión sobre su historia, sus propiedades y su uso en la homeopatía. Homeopatia Méx. 2016, 85, 28-38.

35. Fort, R.S.; Barnech, T.J.M.; Dourron, J.; Colazzo, M.; Aguirre-Crespo, F.J.; Duhagon, M.A.; Álvarez, G. Isolation and structural characterization of bioactive molecules on prostate cancer from Mayan traditional medicinal plants. Pharmaceuticals 2018, 11, 78. [CrossRef]

36. Husain, A.; Indani, A.; Bhutada, P. Hypercholesterolemia effectively managed with homoeopathic medicine Gautteria gaumeri (Yumel): Results from a clinical study in academic clinical set up in north India. Int. J. Adv. Med. 2017, 4, 772. [CrossRef]

37. Godoy-Rodríguez, T. Actividad Antifúngica de Plantas Nativas de la Península de Yucatán Para el Control de Fitopatógenos Poscosecha de Capsicum spp. Tesis de Maestría; Centro de Investigación Científica de Yucatán: Mérida, Yucatán, Mexico, 2019.

38. Saha, A.; Rahman, M.S. Antimicrobial activity of crude extract from Calycopteris floribunsa. Bangladesh J. Microbiol. 2008, 25, 137-139. [CrossRef]

39. Begum, J.; Yusuf, M.; Chowdhury, J.U.; Khan, S.; Anwar, M.N. Antifungal activity of forty higher plants against phytopathogenic fungi. Bangladesh J. Microbiol. 2007, 24, 76-78. [CrossRef]

40. Rinez, A.; Daami-Remadi, M.; Ladhari, A.; Omezzine, F.; Rinez, I.; Haouala, R. Antifungal activity of Datura metel L. organic and aqueous extracts on some pathogenic and antagonistic fungi. Afr. J. Microbiol. Res. 2013, 7, 1605-1612. [CrossRef]

41. Matos, O.C.; Baeta, J.; Silva, M.J.; Ricardo, C.P. Sensitivity of Fusarium strains to Chelidonium majus L. extracts. J. Ethnopharmacol. 1999, 66, 151-158. [CrossRef] 
42. Tian, J.; Zeng, X.; Zhang, S.; Wang, Y.; Zhang, P.; Lü, A.; Peng, X. Regional variation in components and antioxidant and antifungal activities of Perilla frutescens essential oils in China. Ind. Crops Prod. 2014, 59, 69-79. [CrossRef]

43. De-la-Cruz-Chacón, I.; Riley-Saldaña, C.A.; Arrollo-Gómez, S.; Sancristóbal-Domínguez, T.J.; Castro-Moreno, M.; González-Esquinca, A.R. Spatio-temporal variation of alkaloids in Annona purpurea and the associated influence on their antifungal activity. Chem. Biodiv. 2019, 16, 1-14. [CrossRef]

44. Lee, H.S. Fungicidal property of active component derived from Acorus gramineus rhizome against phytopathogenic fungi. Bioresour. Technol. 2007, 98, 1324-1328. [CrossRef]

45. Chen, Y.; Li, J.; Li, S.X.; Zhao, J.; Bernier, U.R.; Becnel, J.J.; Agramonte, N.M.; Duke, S.O.; Cantrell, C.L.; Wedge, D.E. Identification and characterization of biopesticides from Acorus tatarinowii and A. calamus. In Medicinal and Aromatic Crops: Production, Phytochemistry and Utilization; ACS Symposium Series; American Chemical Society: Washington, DC, USA, 2016; pp. 121-143, [CrossRef]

46. Momin, R.A.; Nair, M.G. Pest-managing efficacy of trans-asarone isolated from Daucus carota L. seeds. J. Agric. Food Chem. 2002, 50, 4475-4478. [CrossRef]

47. Perrett, S.; Whitfield, P.J. Anthelmintic and pesticidal activity of Acorus gramineus (Araceae) is associated with penylpropanoid asarones. Phytother. Res. 1995, 9, 405-409. [CrossRef]

48. Phongpaichit, S.; Pujenjob, N.; Rukachaisirikul, V.; Ongsakul, M. Antimicrobial activities of the crude methanol extract of Acorus calamus Linn. Songklanakarin J. Sci. Technol. 2005, 27, 517-523.

49. Dissanayake, M.L.M.C.; Ito, S.I.; Akakabe, Y. TLC bioautography guided detection and biological activity of antifungal compounds from medicinal plant Acorus calamus Linn. Asian J. Plant. Pathol. 2015, 9, 16-26. [CrossRef]

50. Venkatesan, R.; Karuppiah, P.S.; Arumugam, G.; Balamuthu, K. $\beta$-Asarone exhibits antifungal activity by inhibiting ergosterol biosynthesis in Aspergillus niger ATCC 16888. Proc. Natl. Acad. Sci. India 2019, 89, 173-184. [CrossRef]

51. Rajput, S.B.; Karuppayil, S.M. $\beta$-Asarone, an active principle of Acorus calamus rhizome, inhibits morphogenesis, biofilm formation and ergosterol biosynthesis in Candida albicans. Phytomedicine 2013, 20, 139-142. [CrossRef]

52. Cruz, S.; Cáceres, A.; Álvarez, L.; Apel, M.; Henríquez, A. Chemical diversity of essential oils from 15 Piper species from Guatemala. Acta Hortic. 2012, 964, 39-46. [CrossRef]

53. Giovannini, P.; Howes, M.J.R. Medicinal plants used to treat snakebite in Central America: Review and assessment of scientific evidence. J. Ethnopharmacol. 2017, 199, 240-256. [CrossRef]

54. Cáceres, A.; Cruz, S.M.; Gaitán, I.; Guerrero, K.; Álvarez, L.E.; Marroquín, M.N. Antioxidant activity and quantitative composition of extracts of Piper species from Guatemala with potential use in natural product industry. Acta Hortic. 2012, 964, 77-84. [CrossRef]

55. Almeda, F.; Astorga, L.; Orellana, A.; Sampuel, L.; Sierra, P.; Gaitán, I.; Cáceres, A. Piper genus: Source of natural products with anti-tyrosinase activity favored in phytocosmetics. Int. J. Phytocos. Nat. Ingred. 2015, 2, 1-5. [CrossRef]

56. Cáceres, A.; Almeda, F.; Astorga, L.M.; Orellana, A.C.; Sampuel, L.I.; Sierra, P.; Zelada, V.F. Anti-urease activity of native species of genus Piper from Guatemala with potential application in infection control. Int. J. Phytocos. Nat. Ingred. 2018, 5. [CrossRef]

57. Calderón, Á.I.; Romero, L.I.; Ortega-Barría, E.; Solís, P.N.; Zacchino, S.; Jiménez, A.; Espinosa, A. Screening of Latin American plants for antiparasitic activities against malaria, Chagas disease, and leishmaniasis. Pharm. Biol. 2010, 48, 545-553. [CrossRef] [PubMed]

58. Ober, A.G.; Fischer, N.H.; Parodi, F. Jamaicolides AD, four sesquiterpene lactones from Calea jamaicensis. Phytochemistry 1986, 25, 877-881. [CrossRef]

59. Lima, T.C.; de Jesus Souza, R.; da Silva, F.A.; Biavatti, M.W. The genus Calea L.: A review on traditional uses, phytochemistry, and biological activities. Phytother. Res. 2018, 32, 769-795. [CrossRef] [PubMed]

60. Cruz-Estrada, A.; Medina-Baizabal, I.L.; Ruiz-Sánchez, E.; Gamboa-Angulo, M. Effect of Eugenia winzerlingii extracts on Bemuse tabaci and evaluation of its nursery propagation. Phyton. Int. J. Exp. Bot. 2019, 88, 161-170. [CrossRef]

61. Abou-Jawdah, Y.; Sobh, H.; Salameh, A. Antimycotic activities of selected plant flora, growing wild in Lebanon, against phytopathogenic fungi. J. Agric. Food Chem. 2002, 50, 3208-3213. [CrossRef] [PubMed] 
62. Clinical and Laboratory Standards Institute. Reference Method for Broth Dilution Antifungal Susceptibility Testing of Filamentous Fungi; Approved Standard M38-A2; National Committee for Clinical Laboratory Standards: Wayne, PA, USA, 2002.

63. Andrews, J.M. Determination of minimum inhibitory concentrations. J. Antimicrob. Chemother. 2001, 48, 5-16. [CrossRef] [PubMed]

64. Irkin, R.; Korukluoglu, M. Control of Aspergillus niger with garlic, onion and leek extracts. Afr. J. Biotechnol. 2007, 6, 384-387.

65. Martín, J.; Crespo, G.; González-Menéndez, V.; Pérez-Moreno, G.; Sánchez-Carrasco, P.; Pérez-Victoria, I.; Bills, G.F. MDN-0104, an antiplasmodial betaine lipid from Heterospora chenopodii. J. Nat. Prod. 2014, 77, 2118-2123. [CrossRef] 